Ansell N, Hajdu F, van Blerk L, Robson E (in press, 2014) 'Reconceptualising temporality in young lives: exploring young people's current and future livelihoods in AIDS-affected southern Africa' Transactions of the Institute of British Geographers

\title{
Reconceptualising temporality in young lives: exploring young people's current and future livelihoods in AIDS-affected southern Africa
}

\section{Introduction}

Relatively few geographers interested in the lives of children and youth have given consideration to their livelihoods. Yet not only does a livelihoods approach shed light on many aspects of young people's contemporary lives; the dynamism of livelihoods also requires us to think about temporality in young people's lives in new ways. Livelihoods are always temporally structured: activities undertaken today (whether schooling, training or income earning) affect short, medium and long-term futures. In light of growing global concern about sustainability, and given that today's young people generally have long futures and will instigate generational change, better understanding of the temporalities of young lives is vital. There is, however, an entrenched reluctance among geographers to view young people in relation to future adult lives; a reaction to the earlier dominance of developmental psychology which viewed children as adults-in-waiting. A livelihoods approach with a temporal dimension can offer geographers new ways of thinking about young people's lives.

A context in which the interplay between present and future in young lives is particularly evident is Southern Africa, where a severe AIDS pandemic impinges on people's lives in diverse ways. It is widely speculated that AIDS' indirect impacts on young people today will compromise their future livelihoods (Loevinsohn and Gillespie 2003), although evidence is scarce. This paper investigates how AIDS is shaping the relationship between young people's current and future livelihoods. We begin by reviewing research on young people's livelihoods and approaches to temporality in children's geographies and beyond. We introduce our approach to livelihoods and the concepts of livelihood pathways and trajectories, and outline the research design. Specific livelihood pathways are then explored, focusing on: the reasons why young people pursue them (as responses to current and future needs, and their own and their families' security, within changing structural constraints); whether they promote accumulation or depletion of livelihood assets and the consequences for future livelihoods; and the impacts of AIDS on both young people's propensity to pursue the pathways and the long-term outcomes. We also examine complex aspects of livelihood temporalities that cut across these pathways. 
Ansell N, Hajdu F, van Blerk L, Robson E (in press, 2014) 'Reconceptualising temporality in young lives: exploring young people's current and future livelihoods in AIDS-affected southern Africa' Transactions of the Institute of British Geographers

The paper thus advances understanding of young people's livelihoods and how livelihood trajectories are forged, and of the links between AIDS and livelihood sustainability in southern Africa. It also extends understanding of temporality in young lives. By building on the concepts of livelihood pathways and trajectories, but explicitly theorising their temporal dimensions, the paper reconceptualises youth transitions as multi-directional processes that span boundaries, iteratively connecting current and future lives. This has resonance beyond the immediate southern African context, as globally the livelihood activities of young people similarly connect present and future.

\section{Young people and livelihoods}

The attention of geographers and others to young people's livelihoods has hitherto focused mainly on the Global South, where many children contribute substantially to household livelihoods from an early age (Robson 2004). In rural areas particularly, children participate in agricultural and household production and social reproduction and undertake entrepreneurial work in marketplaces (Abebe and Kjorholt 2009;). Children's help is expected and valued by families, within the household (Robson et al 2006), and as contributors to household income (Jaiyebo 2003).

However, beyond 'child labour' concerns (Bourdillon 2000), children's contributions to livelihoods, and the value their work produces, remain largely unrecognised (Abebe 2007). Street children have been shown to accrue dynamic portfolios of assets and employ complex livelihood strategies (Conticini 2005), but children living in other contexts also struggle to support household livelihoods (Abebe and Kjorholt 2009). Livelihoods are relational, thus options and expectations are circumscribed by both family pressures and changing structural conditions (Katz 2004). In Ethiopia, for instance, the move to cash cropping is expanding children's domestic workloads and rendering their livelihood participation increasingly independent of adults (Abebe 2007).

Most research on young people's livelihoods, in geography and beyond, has focused on the immediate. However, young people's livelihood participation affects not only their day-to-day contributions to personal and family sustenance but also their future lives. Research relating to children's future livelihoods usually focuses on prospects foregone. Many studies of child labour, for instance, emphasise 
Ansell N, Hajdu F, van Blerk L, Robson E (in press, 2014) 'Reconceptualising temporality in young lives: exploring young people's current and future livelihoods in AIDS-affected southern Africa' Transactions of the Institute of British Geographers

harmful long-term consequences of missed schooling (Heady 2000), despite evidence that education prepares youth inadequately for future livelihoods, and that in Africa even urban labour market opportunities are seldom accessed principally through education (Chant and Jones 2005). Other research has revealed how young people in difficult contexts often adopt risky livelihood strategies such as commercial sex work that compromise their future wellbeing (Hampshire et al 2008). Even those undertaking socially positive roles, such as young caregivers, sometimes find subsequent livelihood options constrained, particularly where confinement to the home leaves them socially marginalised (Dahlblom et al 2009). Little research has examined the interrelation of present and future livelihoods, including young people's future orientation in making livelihood decisions, or positive future outcomes of their current livelihood activities. This temporal dimension is important for those researching young people's geographies in all contexts; as we demonstrate, present and future are inextricably interwoven and together shape future outcomes for young people. The next section explores why researchers have hitherto been reluctant to engage with temporality and therefore to fully embrace its complexity.

\section{Young people's temporalities: being and becoming}

Research with young people has had a rather ambivalent relationship with notions of temporality. Horton et al (2008:342) contend that much research in children's geographies focuses on temporalities 'em-bodily becoming, developmental stages, social transitions, 'growing up', 'coming of age', or simply 'going on"- but opine that children's geographies have not been an explicit focus for temporality in human geography. The reluctance to embrace temporality within childhood studies relates to a longstanding critique of developmental psychology, once the principal framework for studying children's lives. Prior to the 1990s, social science generally viewed children as future adults rather than significant in their own right. Rejecting this approach, James et al (1998) called for children to be understood as 'human beings' rather than 'human becomings', emphasising their everyday realities, not their likely futures. In recent years recognition has grown that children, like adults, are living lives of constant change, leading to a new embrace of the 'becomingness' of children (Horton and Kraftl 2006), although focused predominantly on the ongoing everyday. A useful stance is that of Uprichard (2008:303), who draws on complexity literature in which 'time and change as 'being and becoming' are seen as necessary 
Ansell N, Hajdu F, van Blerk L, Robson E (in press, 2014) 'Reconceptualising temporality in young lives: exploring young people's current and future livelihoods in AIDS-affected southern Africa' Transactions of the Institute of British Geographers

preconditions of all physical and social things' to argue that children are best understood as both 'being and becoming'; that their present and future lives are fundamentally interwoven and research should consider both together.

This contestation in childhood studies is paralleled in youth studies. Quantitative sociological studies of youth transitions are critiqued from a cultural studies perspective, emphasising youth here and now (MacDonald et al 2001). The youth transitions literature has, nonetheless, inspired geographers to explore the increasingly diverse, complex and prolonged transitions to adulthood of Western youth (Valentine 2003). This framework has been applied to urban Africa, where rapid social change is disrupting transitions to adulthood, hampering young people's efforts to sustain viable livelihoods and preventing them from accumulating the resources required to achieve social adulthood (Langevang 2008).

Recent work, critical of youth transitions studies that emphasise attainment of individualised autonomous adulthood (see Jeffrey 2010), has begun to stress relational aspects of growing up: the roles played by families and peers (Hopkins and Pain 2007), other generations (Mabala 2011), wider social relations (Langevang 2008) and contexts of poverty (van Blerk 2008). Punch (2002) has shown that, for Bolivian youth, transition often culminates in 'negotiated interdependence' rather than independence. Broader relational concepts of lifecourse, rather than a limited focus on transition, encourage attention to other life events and processes (Bailey 2009), including unexpected 'fateful moments' (Worth 2009), 'vital conjunctures' (Johnson-Hanks 2002) and rites of passage (Teather 1999). These approaches also highlight the complex and temporally uneven ways in which challenges confront young people (Jeffrey 2010).

Temporality in young people's livelihoods is significant at several levels, from time-space routines (Harker 2005) and the diurnal modulation of children's activities (Robson 2004); through the seasonal patterning of work in rural environments (Abebe and Kjorholt 2009); to the evolving 'street careers' of those pursuing livelihoods on Tanzanian city streets (Evans 2006) and imagined future migrations of those seeking livelihoods in Ghanaian cities (Langevang and Gough 2009). Research with working children in Ethiopia has explored how children view begging strategically within a purview of their futures, as a temporary activity (Abebe 2008). Similarly, young women from northern Ghana work 
Ansell N, Hajdu F, van Blerk L, Robson E (in press, 2014) 'Reconceptualising temporality in young lives: exploring young people's current and future livelihoods in AIDS-affected southern Africa' Transactions of the Institute of British Geographers

temporarily as headloaders in Accra's markets to save money prior to marriage (Grieco et al 1996). Worth (2009) employs a concept of futurity, drawing on the work of Grosz (1999) to explore young people's future orientation as they conceptualise and make choices about their transitions to adulthood. While Worth focuses on the role of the future in constructing identity, our research examines how young people bring the future into play in making decisions about immediate livelihood activities, and the likely implications for future livelihoods. We thus see the temporality of youth transitions as a twoway process, created in the iteration between present and future.

\section{Conceptual framing: pathways, trajectories and livelihood temporalities}

In exploring links between current and future livelihoods, we address two related areas: the ways in which young people's current and future needs and aspirations impinge on the livelihood activities; and the implications of young people's current livelihoods for their future prospects. In doing so we draw on and further develop an approach outlined by de Haan and Zoomers (2005). Critiquing 'livelihood strategies' as imposing an ex-post label on behaviours that are seldom fully intentional, these authors propose the notion of 'livelihood pathways', to signify broad societal patterns of livelihood activities. Avoiding a crude intentional/unintentional dichotomy, the pathways concept recognises that livelihoods emerge, not as responses to a stable vision of the future, but as incremental outcomes of individual strategic behaviour embedded in a 'historical repertoire' of possibilities, through 'coordination with other actors' (i.e. relationally), and within structural constraints. They adopt the term 'livelihood trajectory' to refer to specific activities pursued by individuals. These concepts can offer new insight into youth transitions, but require a stronger theorisation of their temporal dimensions.

De Haan and Zoomers are concerned with livelihood activities actually practised. Building temporality into the model, we use the term 'livelihood trajectory' more broadly to embrace both thoughts and actions focused on young people's sustenance of themselves and their families, recognising that trajectories develop over time, with aspirations shaping plans and plans shaping decisions and actions, but intervening events and circumstances contributing greatly to the dynamic process. Trajectories seldom reflect one-off decisions so much as a progression of actions with greater or lesser strategic 
Ansell N, Hajdu F, van Blerk L, Robson E (in press, 2014) 'Reconceptualising temporality in young lives: exploring young people's current and future livelihoods in AIDS-affected southern Africa' Transactions of the Institute of British Geographers

intent. Indeed young people may pursue multiple livelihoods simultaneously or consecutively, as part of a strategic course of action or due to failure or happenstance.

In our conceptualisation, livelihood trajectories are produced In response to interwoven present and future needs and aspirations that are complexly bound to wider contexts that are social, cultural, political and economic. Planning and decision making are not, however, simply cognitive processes wherein sovereign rational individuals weigh up options. There are non-rational and also non-conscious aspects: attitudes, values, personal preferences for immediate relative to future benefits, memory, affect and emotion all influence the trajectories individual young people pursue (Cass and Walker 2009). Livelihood decisions are also profoundly relational: in making decisions about their own lives, young people almost always consider (consciously or otherwise) the views, needs and potential contributions of others, now and in the future. Relationships impose demands, expectations, desires and duties as well as providing opportunities (see Mabala 2011 on how intergenerational frictions shape youth livelihoods). Trajectories are drawn from the 'historical repertoires' available in particular communities. Moreover, all livelihoods have particular requirements, and these are affected by social, cultural economic and political processes operating at scales ranging from local to global. Thus it is within (sometimes stringent) structural, community and family constraints that young people 'envision paths into the future' (Langevang and Gough 2009:752) and make livelihood choices (Abebe 2007).

Figure I

The relationship between current and future livelihoods is complexly iterative. While livelihood choices reflect (albeit unstable) visions of the future as well as the present, young people's activities at any point affect both present and future wellbeing, irrespective of any thought-through strategy. Activities today shape the future but not straightforwardly, and outcomes are often unanticipated. Engagement in dayto-day livelihood activities may, for instance, provide experience that later proves valuable, but conversely may deprive young people of more useful opportunities to accrue livelihood assets (Dahlblom et al 2009). The accumulation of livelihood assets, categorised (albeit problematically) as financial, social, human, physical and natural capital (Chambers and Conway 1991), should enhance long term livelihood security; conversely, their depletion limits future options. 
Ansell N, Hajdu F, van Blerk L, Robson E (in press, 2014) 'Reconceptualising temporality in young lives: exploring young people's current and future livelihoods in AIDS-affected southern Africa' Transactions of the Institute of British Geographers

This paper applies this conceptual framework to examine one specific influence on livelihoods: AIDS. Despite declining HIV-prevalence rates, growing numbers of children live in affected households; $14 \%$ of under-18s in Lesotho and $8 \%$ in Malawi have lost a parent to AIDS (UNAIDS 2010), with orphanhood increasingly common as children grow older. AIDS' effects on a family might influence young people's livelihood preferences (for instance, encouraging them to prioritise current rather than future wellbeing), diminish their capacity to enact plans and potentially alter the consequences of their actions. Moreover, AIDS affects not only young people's immediate circumstances but also wider societal conditions, including demand for particular types of work. However, AIDS is never an isolated factor; it interacts with other processes. Ultimately, we show that the coincidence of events and processes produces an uneven terrain in which outcomes may be stochastic products of 'happenstance' as much as deterministic structural conditions or an individual strategic plan. By examining livelihood trajectories in this way and exploring how the impacts of AIDS can shape and produce series of events, we demonstrate why children's geographers should examine the multi-dimensional temporalities of youth transitions; AIDS in Africa might be substituted by a range of other processes in other contexts.

\section{The research}

Research on livelihood sustainability faces the challenge of anticipating future change. Murray (2002) recommends combining retrospective (tracking change), circumspective (current patterns) and prospective (policy influencing) approaches. Our research explored young people's past and current livelihood activities and future plans, and sought to anticipate possible outcomes of their trajectories. We developed in-depth case studies of two small villages: Flora spent three months living in each, gaining a fuller understanding of young people's livelihoods (particularly temporal and relational dimensions) than possible through more extensive approaches. The other authors also participated in the village-level research, including a six-day intensive follow-up in each community. While our findings are not statistically generalisable, the case study approach enables analytical generalisation founded on in-depth understanding (Yin 1994).

We adopted a broadly participatory approach, recognising that young people are meaning-making agents and that participatory methods produce 'situated, rich and layered accounts' (Pain 2004, 653), 
Ansell N, Hajdu F, van Blerk L, Robson E (in press, 2014) 'Reconceptualising temporality in young lives: exploring young people's current and future livelihoods in AIDS-affected southern Africa' Transactions of the Institute of British Geographers

albeit not unmediated perspectives (Kesby 1999). Children, especially, may best express their insights when empowered through self-directed methods (Boyden and Ennew 1997). However, while participatory methods proved useful in constructing broadly consensual knowledge on young people's aspirations and prospects, they were less effective at eliciting individual stories of AIDS' impacts on experiences and situations (Ansell et al 2012). To explore this sensitive and complex area, we undertook individual life-history interviews. We recognise, however, the provisionality and fluidity of young people's aspirations for the future, and the limitations of any method of eliciting these.

The research took place in Malawi and Lesotho, both countries with insecure rural livelihoods and high HIV prevalence. The case study villages, Nihelo in southern Malawi and Ha Rantelali in Lesotho, were selected because they were small (facilitating familiarity), located in high AIDS-prevalence areas, ${ }^{1}$ engaged in varied (insecure) livelihoods, and were 'typical' rural communities (distant from main roads and not specifically targeted by development interventions). Nihelo is in impoverished, densely populated Thyolo district, reliant on subsistence agriculture and small-scale businesses. Ha Rantelali, by contrast, lies in the sparsely populated Maluti Mountains. Here, livelihoods historically relied on income from migrant mineworkers (now much diminished ${ }^{2}$ ) supplemented by livestock herding, subsistence agriculture playing a smaller role. Whereas marriage practices in Nihelo are matrilineal and matrilocal (property transferred through the female line and husbands settling in their wives' villages), Ha Rantelali is traditionally patrilineal and patrilocal (property passed from fathers to sons; married women joining their husbands' families). Between them, the two villages allow insight into diverse situations, highlighting both differences and similarities across contexts.

The participatory research involved eighty young people aged $10-24{ }^{3}$ This age range spans the roughly parallel transitions most young people experience (leaving school, leaving home, marriage, parenthood). In each village, more than $50 \%$ of resident young people participated, around half of whom were considered AIDS-affected, having experienced chronic illness or death within their households. ${ }^{4}$

\footnotetext{
${ }^{1}$ At the primary school nearest Ha Rantelali, $23 \%$ of students in Standard 1 were orphans rising to $56 \%$ in Standard 7.

211 households included miners in 1997, falling to 4 in 2008.

${ }^{3}$ Owing to uncertainties around age, some were subsequently believed to be older.

${ }^{4}$ Chronic illness was used as a proxy for AIDS because cause of death is seldom openly discussed.
} 
Ansell N, Hajdu F, van Blerk L, Robson E (in press, 2014) 'Reconceptualising temporality in young lives: exploring young people's current and future livelihoods in AIDS-affected southern Africa' Transactions of the Institute of British Geographers

In each village, following a household profiling exercise, young people were invited to join one of four groups organised by gender and age. Broadly, 10-17-year-olds were separated from 18-24-year-olds, reflecting legal status, although most young women opted for groups based on marital status rather than chronological age. Each group attended 10 participatory sessions to express opinions, share experiences and discuss key issues (see Ansell et al 2012). All willing 18-24-year-olds (47 in total) subsequently participated in in-depth interviews: these older youth, having made multiple livelihood decisions, could reflect on their trajectories. Preliminary findings and implications were later discussed with young people and their communities in participatory workshops.

No established frameworks exist for analysing participatory research, beyond involving participants. Throughout the fieldwork, researchers, participants and national steering groups (representatives of government, NGOs, UN agencies and local academics) engaged with the emerging findings, relating these to their own knowledge and experience. Following the fieldwork, transcripts, notes and visual materials were entered into NVivo ${ }^{5}$ for coding and in-depth analysis. The data comprised empirical information about livelihood trajectories entwined with young people's explanations of how these trajectories were forged. We therefore used matrices to identify common livelihood trajectories, how these differed between communities and individuals, and their association with AIDS and other factors. We explored the transcripts for young people's accounts of their trajectories, identifying recurring themes, but recognising that non-rational and non-conscious elements of trajectories are not easily articulated. The diverse sources of information were therefore triangulated and rigorously interrogated.

\section{Livelihood pathways and outcomes}

The participants' current livelihood activities are set out in Table I. While most under-18s still attended school, the prominent activities among older youth in Lesotho were livestock herding (among young men) and subsistence farming and domestic work (among young women). In Malawi activities were more diverse, and less rigidly gendered, with many young people engaged in growing vegetables for sale on dimba (riverside plots irrigated by watering can); ganyu (casual labour) for other villagers; and a host of informal businesses; besides cultivating maize and cassava in rainfed fields. Table I is far from comprehensive: ten young people from Ha Rantelali were currently working elsewhere (four domestic workers, three herding, a taxi driver, a factory worker and a shop worker), and a further fourteen were

\footnotetext{
${ }^{5}$ Qualitative data analysis software.
} 
Ansell N, Hajdu F, van Blerk L, Robson E (in press, 2014) 'Reconceptualising temporality in young lives: exploring young people's current and future livelihoods in AIDS-affected southern Africa' Transactions of the Institute of British Geographers

studying elsewhere, including two at university. Moreover, all young people undertook varied activities on a daily, weekly and seasonal basis, to support themselves and their households. In Nihelo, for instance, Yamikani $(17)^{6}$ attended school but also worked in the fields, irrigated a dimba, and looked after the household's pigs and rabbits; Lucius (13) combined school with farming, basket making and ganyu.

Table I

Alongside these short-term cycles of activity are longer term shifts: the table provides only a snapshot. Many older Malawian youth had previously run small businesses, generally baking and selling food or trading in goods such as fish or maize. In both countries more than a third of the older youth had been employed, mostly in town or (in Malawi) on agricultural estates.

Our focus is less on these temporal patterns than on how livelihood activities relate to current and future considerations. Young people's activities focused partly on their own and their families' immediate welfare, siblings' needs (including school fees) figuring prominently, especially among orphans. Many activities were also geared towards future livelihoods (their own and their families'). Using the sustainable livelihoods framework terminology (Chambers and Conway 1991), young people were engaged (intentionally or otherwise) in accumulating assets: human capital, through formal and informal learning; natural capital, through for instance acquiring land via marriage; social capital through forming useful friendships; and physical capital through accruing livestock or tools. However, the extent to which they consciously planned for the future varied considerably, depending in part on individual and family circumstances.

Below we explore five key livelihood pathways: schooling (geared almost exclusively towards future livelihoods), herding (practised widely by boys in rural Lesotho), casual employment (undertaken in both villages, but especially Nihelo), informal business (ranging considerably in scale and character and including cash cropping) and migrant work (including factory, shop, agricultural estate and domestic work). Each pathway requires different forms of knowledge, experience, equipment and other resources and some are highly gendered. Rewards (and levels of security) vary within and between pathways. In Nihelo, for instance, casual or estate work earns the equivalent of around 40p/day; on a good day, radio

\footnotetext{
${ }^{6}$ Pseudonyms are used for all individuals. Age and village are specified where relevant.
} 
Ansell N, Hajdu F, van Blerk L, Robson E (in press, 2014) 'Reconceptualising temporality in young lives: exploring young people's current and future livelihoods in AIDS-affected southern Africa' Transactions of the Institute of British Geographers

repair might generate $£ 1.40$ and bicycle repair $£ 3.20$. In Ha Rantelali, a herdboy earns a cow a year (worth around f70); a domestic worker is paid f13/month; while the official minimum monthly wage of $£ 49$ applies to public works schemes and migrant factory work. We have not included subsistence agriculture, which is a default option, not an actively chosen strategy. Everyone engages in agriculture but land is scarce and few households in either village grow sufficient food to live on. Access to alternative income sources is therefore the focus of this paper. Neither do we discuss marriage as a livelihood strategy, although it may serve as such; this will be addressed elsewhere. Drawing on our discussion of livelihood trajectories above, we consider the factors shaping young people's pursuit of each of the pathways: how they are locally regarded; their perceived benefits in relation to current and future security; the roles played by kin and others; and constraints limiting their accessibility. We also consider outcomes of the pathways, and whether the indirect effects of AIDS influence young people's pursuit of them and their chances of success.

\section{Schooling}

In both Lesotho and Malawi schooling comprises primary (Standards 1-7 in Lesotho, 1-8 in Malawi) and secondary (Forms A-E in Lesotho; 1-4 in Malawi) stages. Primary education is now officially free, and attended by over $80 \%$ of primary school-aged children in both countries (UNICEF 2011). . Students who pass primary leaving examinations may proceed to secondary school which is expensive and attended by only $20-25 \%$ of children (ibid). At both levels, education is predominantly academic, geared around public examinations. End of secondary school examinations are the minimum qualifications for most formal employment, but are attained by very few rural youth. Most young people under 18 in both communities attended school; some continued much longer but few progressed beyond primary school. As a livelihood activity, schooling generates no immediate returns, but is widely considered an investment in the future. Almost all schoolchildren, especially in Ha Rantelali, envisaged formal sector careers requiring secondary education. . The importance attached to schooling was considerable: Puseletso, a young Mosotho ${ }^{7}$ woman, insisted: 'today life is about education, if you're not educated it's

\footnotetext{
${ }^{7}$ Lesotho's people are Basotho, singular Mosotho.
} 
Ansell N, Hajdu F, van Blerk L, Robson E (in press, 2014) 'Reconceptualising temporality in young lives: exploring young people's current and future livelihoods in AIDS-affected southern Africa' Transactions of the Institute of British Geographers

hard to have a livelihood, it's not easy to survive'. Most, therefore aspired to continue education as long as possible.

Schooling requires a substantial immediate investment, however. Although in theory free, primary education carries costs. Contrary to national policy, schools require expensive uniforms that must be kept clean (requiring expensive laundry soap). Pupils also need notebooks, pencils, books and sometimes lunch. Moreover, 'development fees', for improvements to teachers' housing, were raised from Nihelo children annually; those whose parents failed to pay were excluded from end-of-year exams, precluding progression to the next class. Moreover, immediate pressure to support themselves or their families stopped some children attending to their futures. Makwete from Nihelo, for instance, left Standard 2 and 'rushed to work to get some clothes'.

Secondary schooling was more expensive still. Ha Rantelali's nearest school charged $f 75$ annually in fees, with uniforms an additional $£ 67$ and public examinations approaching $f 65$. Such costs generally require sustained family support. Regardless of aspirations, very few participants progressed to secondary school. Young people's strategic plans were circumscribed by their financial dependence on others and structural forces shaping access to schooling.

Nonetheless, faith in education's capacity to transform their future livelihoods inspired a minority of young people to work to earn their own fees. Wilson (19), who was taking a year off school for this purpose, explained: 'I see that school is important. Because there are some [jobs] that you can find if you finish school ... There might be some [jobs] that will need someone who has gone to school'. Many primary school children, recognising their families could/would not afford secondary school, envisioned spending a few years earning money in order to return to school. For these, income earning related to perceived future rather than present needs, illustrating the complex ways in which young people's livelihood trajectories incorporate activities designed to secure the future.

In contrast to these deliberative plans, leaving school was seldom a strategic decision in which present was weighed against future, or alternative futures weighed up; nor was it entirely freely made. Usually, leaving school was precipitated by immediate circumstances, reflecting familial and wider contexts: failure of end-of-year exams (often reflecting irregular attendance, itself an outcome of challenging times); parental sickness or death; poverty (manifesting in lack of uniform, shoes, warm clothes or 
Ansell N, Hajdu F, van Blerk L, Robson E (in press, 2014) 'Reconceptualising temporality in young lives: exploring young people's current and future livelihoods in AIDS-affected southern Africa' Transactions of the Institute of British Geographers

laundry soap); illness; pregnancy or marriage. ${ }^{8}$ Only among the Basotho boys was leaving school a deliberate choice. Most said they left to take up fulltime herding, because they believed it would secure their future better than schooling, rather than because it met their immediate needs, although immediate circumstances were sometimes influential. Hlobola explained his preference for accruing animals by herding: 'I think I felt they were more important than school because I could use them for ploughing'. Motivations for herding are considered further below.

It might seem likely that AIDS-affected young people would (have to) forego future-oriented education to secure immediate needs or fulfil obligations to others. However, the evidence suggests otherwise. While several participants reported having left school upon the death of a parent (usually a father), school attendance was actually higher among AIDS-affected than unaffected participants. Among 18-24year-olds, those deemed AIDS-affected had on average progressed further through school in both villages (young men in Lesotho by a full four years). Of the fourteen young people from Ha Rantelali studying elsewhere, ten were AIDS-affected. While these quantitative findings cannot be generalised, they corroborate studies elsewhere suggesting orphanhood affects school attendance less negatively than once believed (Ainsworth and Filmer 2006). The high secondary attendance among AIDS-affected youth largely reflects access to bursaries which remove the immediate cost. Although in theory bursaries are available to other vulnerable children, all seven recipients of secondary school bursaries were orphans, ${ }^{9}$ and young people in both villages believed only orphans were eligible. Moreover, those affected by AIDS (and their surviving parents/guardians) often prioritised their future wellbeing when confronted with adverse immediate circumstances. Mary's education, for instance, was discussed at her father's funeral, where an uncle volunteered to pay her secondary fees. She explained 'He came to the funeral and I was crying that my future has been doomed and that's when he said don't worry I will pay for you'. David's (17) father discussed his education with him before he died and his relatives subsequently helped him continue schooling. Combined with access to bursaries, this future-orientation among relatives enables many AIDS-affected young people to remain in school. Thus the educational trajectories of AIDS-affected youth are constructed relationally to both the actions of kin and wider structural policies.

\footnotetext{
${ }^{8}$ Contrary to government policy, schools expelled students who became pregnant or married.

${ }^{9}$ Bursaries are provided by government in Lesotho and local NGOs in Nihelo.
} 
Ansell N, Hajdu F, van Blerk L, Robson E (in press, 2014) 'Reconceptualising temporality in young lives: exploring young people's current and future livelihoods in AIDS-affected southern Africa' Transactions of the Institute of British Geographers

Given the time, money and effort young people and their households invest in education, the outcomes merit consideration. As a future-oriented strategy, schooling does not necessarily enhance livelihood prospects. According to Lesotho's Labour Force Survey (BOS 2008), 15-24-year-olds with secondary education are more likely economically inactive than those with only primary education, and of employed secondary school leavers, $81.7 \%$ work for private households, mostly in agricultural roles (see also Ansell 2002). Apart from the teacher in Ha Rantelali and three builders in Nihelo, the livelihood ventures of secondary-educated participants were no more secure than others. Of the seven young people from Ha Rantelali working in Maseru, only three had secondary education. Of these, two were domestic workers and one worked in a factory. Disappointing outcomes sometimes inspired further investment: secondary-educated Wilson acknowledged education had not yet benefited him, but was confident it would when he reached the right level.

Temporality, then, is important for understanding youth transitions through education. Exploring education transitions reveals multiple and iterative interconnections between present and future lives. Pursuit of education shapes young people's futures but is also a response to anticipated or desired futures. Moreover, aspiring to education (as part of a long-term plan) drives young people to engage in income generation in the present.

\section{Casual rural labour}

In both villages many young people's livelihood trajectories involved casual work, for cash or food. Few in Lesotho considered this a key activity, although some undertook temporary or ongoing informally contracted work such as ploughing, childminding or housekeeping. In Nihelo, by contrast, ganyu (casual work) is fundamental among the historical repertoire of livelihood pathways. Spanning activities including agriculture, domestic tasks and construction work for neighbours, ganyu was a principal livelihood activity of almost half the 18-24-year-olds, male and female, though usually a short-term commitment..

Casual labour is often considered a livelihood strategy for people in desperate situations, addressing immediate needs but increasing long-term vulnerability by eroding human, natural, physical, financial or 
Ansell N, Hajdu F, van Blerk L, Robson E (in press, 2014) 'Reconceptualising temporality in young lives: exploring young people's current and future livelihoods in AIDS-affected southern Africa' Transactions of the Institute of British Geographers

social capital (Bryceson 2006). . For a family head, ganyu may reduce the time available for their own farming activities. Some young people valued it only for accessing food in times of hunger, such as Malawi's 2001/2 food crisis. Other situations also demanded immediate income: Edison (22), for instance, regretted having to abandon his education and seek ganyu when his girlfriend became pregnant, requiring him to prioritise their collective present over his personal future:

I could study before getting married but this [marriage] seemed to disturb me. I was busy looking for ganyu to assist my family and so the problems became worse ... the way I am now, the future is not good mainly on the part of education

However, many Malawian youth without dependants, whose parents/guardians provided their food and shelter, viewed ganyu in relation to the future.. Wilson (cited above) did ganyu to pay his secondary school fees. Julita planned to 'push herself hard' cultivating other people's fields to earn money to invest in trading fish. Similarly, 13-year-old Tiamike viewed ganyu as part of a future-oriented strategy for launching his career as a driver:

First I will have to find some ganyu. When I've done the ganyu, the money from there has to be invested in a dimba and after the end of the season is when I will pay the fees [for lessons]

While, realistically, Tiamike's earnings would be insufficient for driving lessons, a few young people had successfully used ganyu to invest in longer-term ventures. Margret and her husband did ganyu to raise funds to plant tomatoes on their dimba. Rex was used the proceeds of work clearing trees to start fish trading. However, while personal circumstances allowed some young people to use ganyu in a futureoriented way, ganyu is poorly paid, and most young people recognised its limitations. Wyson (20) planned to do ganyu for three years to invest in trading groundnuts; when asked whether he might instead use the money to return to school, he explained 'the savings cannot reach up to [f8]'.

Pursuit of ganyu may thus reflect prioritisation of present or future, and of individual or family needs. Unlike education, opportunities are not structurally constrained. Demand is widespread, especially in Malawi, though somewhat shaped by social networks. In Nihelo, opportunities for recently married men were limited: Jackson's wife had moved temporarily to his village because, until better known, he would not find ganyu in hers. Some children also complained of age-based exclusion, associated with perceived 
Ansell N, Hajdu F, van Blerk L, Robson E (in press, 2014) 'Reconceptualising temporality in young lives: exploring young people's current and future livelihoods in AIDS-affected southern Africa' Transactions of the Institute of British Geographers

capacities for work. As a livelihood trajectory, then, ganyu depends on the opportunities proffered, as personal and familial income requirements.

AIDS-affected young people might be expected to have to prioritise their own and their families' immediate needs, and therefore favour livelihood pathways involving casual work. Indeed, evidence suggests AIDS-affected households disproportionately resorted to ganyu during the $2001 / 2$ food crisis (Dorward et al 2006). However, fewer AIDS-affected young people undertook ganyu in Nihelo compared to those unaffected, and neither of the two under-18s for whom ganyu was a main livelihood activity was AIDS-affected. Reasons for this are unclear. It is unlikely to be attributable to difficulties finding work. Although sick individuals might not participate, no one suggested AIDS-related factors related, such as the burden of care, would preclude young people from undertaking casual work. It is possible that diminished social networks associated with AIDS might restrict opportunities, but no young people referred to such difficulties. Nor were those affected by AIDS more or less likely than others to (plan to) use ganyu to finance a future livelihood.

Rather than conceptualising 'starting work' as crossing a boundary to adulthood, a focus on temporalities in the pursuit of casual labour reveals a more nuanced and complex picture of youth transitions. Casual work may be undertaken as a reflex response to an immediate need, or in strategic pursuit of a plan requiring money. Moreover, rather than a long-term 'transition', casual work is negotiated day-to-day, commonly in support of other elements of transition.

\section{Herding}

In Lesotho, livestock herding is a form of contracted (but unregulated) informal employment for some; a family duty for others (Bissell et al 2000). In rural areas it is valued for socialising boys into responsible adulthood (Lefoka 2006). It dominates the 'historical repertoire' as almost the only regular work available to rural boys, and figures in most livelihood trajectories. In Ha Rantelali, most young men reported having left school to herd and all but two of the out-of-school 10-24-year-old boys/men were herding. 
Ansell N, Hajdu F, van Blerk L, Robson E (in press, 2014) 'Reconceptualising temporality in young lives: exploring young people's current and future livelihoods in AIDS-affected southern Africa' Transactions of the Institute of British Geographers

Unlike the casual labour described above, herding requires long-term commitment and promises both immediate and longer-term pay-offs. Herding for another family secures immediate sustenance: food and accommodation, albeit rudimentary, are provided. For many boys, however, herding was a futureoriented choice, as Relebuhile (20) explained:

Relebuhile: I left school because I wanted to herd the animals. I'm herding for my own family, and a younger brother is also herding. My other two brothers are schooling. [...] this is our choice because our parents sent us all to school but we decided school was a waste of time. [Our parents] were very upset and they were forcing us but we wanted to be herdboys [...] because my home flock didn't have a herdboy so the animals were getting finished.

Interviewer: When you were at school, did you think it was boring or were you doing fine?

Relebuhile: I was enjoying myself very much but still the animals came first.

Interviewer: How do you like it now as a herdboy?

Relebuhile: I like it! I like being a herdboy because I am going to have my own animals.

While the immediate situation (the animals were getting finished) was a proximate cause of Relebuhile's decision, the motivation was future-oriented: to have his own animals. Education would not, in Relebuhile's view, deliver the future he wanted. Even where leaving school was a response to an immediate labour shortage, boys were seldom simply prioritising present over future. Rather, herding was rationalised as an alternative to schooling, promising accumulation of cattle, a long-standing currency in Lesotho, in place of educational qualifications.

Herdboys employed by unrelated families are usually paid one cow a year; as the cattle breed their herds increase. Those working for their own families may eventually benefit from the herd's expansion. The cattle are both culturally and economically important. They serve as bridewealth payments (marriage entitles young men to land, and thus enhanced livelihood security), and financial capital. Few young men continue herding after marriage. Most envisaged futures in farming and cattle ownership, but some viewed their cattle as a resource for alternative futures. Khotso, for instance, planned to sell the cow he would earn to pay for truck driving lessons. Sechaba planned that once he had six cattle, he 
Ansell N, Hajdu F, van Blerk L, Robson E (in press, 2014) 'Reconceptualising temporality in young lives: exploring young people's current and future livelihoods in AIDS-affected southern Africa' Transactions of the Institute of British Geographers

would sell them, move to Maseru, buy a sewing machine and start a business producing school uniform jerseys.

Herding is a profoundly relational livelihood pathway. Unlike Relebuhile, some young men herded at their guardians' insistence. Most who herded willingly considered not only their own current and future security, but their families' needs and desires. Moreover, parents/guardians controlled the disposal of herdboys' earnings: Hlobola (22) explained 'If they disagree then I cannot sell'.

Because day-to-day subsistence is provided and plentiful vacancies exist, herding might be expected to attract orphans disproportionately. The herdboys themselves suggested this was so, yet only three of the six boys herding for unrelated families in Ha Rantelali were orphans. That AIDS-affected young men were not overrepresented is because almost all young men eventually drop out of school to herd, but those affected by AIDS usually remain in school longer. Moreover, the two young men who were neither students nor herding were both orphans (one was a teacher, the other farming). Conceivably, by staying in school, AIDS-affected youth might be slower to accumulate the resources needed to marry and establish an independent livelihood.

While apparently offering both current and future benefits, herding is a risky livelihood pathway. Cattle are vulnerable to drought (a quarter of those in Ha Rantelali died in 2007), disease and armed cattle theft, thus cattle accumulation is uncertain. Because employers determine their working conditions (food, time off, penalties for loss or injuries to animals) herdboys are vulnerable and many are abused (Bissell et al 2000). Being paid annually diminishes their bargaining power: many forwent payment to switch employer. Moreover, the near-continuous time-commitment required limits opportunities to invest in other assets. Although earnings might later be invested in learning skills or starting a business, simultaneously combining herding with other livelihood-related activities is almost impossible. Relebuhile mentioned he would like to acquire skills from the builders working at his home, and Letsema would have attended school, but herding duties prevented both.

Young men's engagement in herding exemplifies how youth transitions span present and future in nonlinear ways. Distant future plans may require urgent actions in response to current situations. Herding 
Ansell N, Hajdu F, van Blerk L, Robson E (in press, 2014) 'Reconceptualising temporality in young lives: exploring young people's current and future livelihoods in AIDS-affected southern Africa' Transactions of the Institute of British Geographers

also reveals how young people engage with 'historical repertoires'. While the usual way to accumulate bridewealth cattle and achieve a transition to adulthood through marriage, the pathway is not deterministic. Individually, boys take up herding due to relational pressures, and ideas about how it relates to their future aspirations.

\section{Starting a business}

The livelihood trajectories of many young people in Malawi and some in Lesotho involved business. In Nihelo, older youth had often baked and sold food or traded goods such as fish or maize. Others grew irrigated vegetables for sale. A few worked as builders and one butchered pigs. One young man from $\mathrm{Ha}$ Rantelali, made tables and coffins, a young woman made jerseys, and several others brewed local beer for sale.

Business fundamentally involves investing for future returns, either short or longer term. In Nihelo, starting a business was common in transitions to adulthood. Unlike in Ha Rantelali, young people were not expected to contribute to their parents' households, but were expected to support themselves at an earlier age, usually establishing independent households within a year or two of marriage. Typically, after leaving school and before marriage conferred new responsibilities, they experimented with different business ideas. Many unmarried school leavers received small loans from parents to pay for the inputs and equipment required for even micro-businesses such as tomato growing or selling cooked snacks (ingredients for a batch of scones, for instance, cost 65p). Unlike ganyu, business was considered a respectable way of generating regular income, particularly by young women; many aspired to it, though not all could access capital.

Business was also viewed as a way of securing future livelihoods. Young people in both communities outlined diverse potential ventures: some younger Malawian boys wanted to repair radios or become motor mechanics, and while most school children in Ha Rantelali aspired to formal sector jobs, some school-leavers hoped to start egg production, building or making school uniforms. Planning was often highly strategic, options being assessed in terms of relative start-up and running costs, time commitments and match with personal talents. Some businesses such as building or carpentry required 
Ansell N, Hajdu F, van Blerk L, Robson E (in press, 2014) 'Reconceptualising temporality in young lives: exploring young people's current and future livelihoods in AIDS-affected southern Africa' Transactions of the Institute of British Geographers

investment in acquiring skills; others such as bicycle taxis demanded substantial capital. Several young people (e.g. Tiamike, above) envisaged using one business to accumulate capital to launch a more lucrative business .

Significantly, AIDS-affected young people were as likely as others to have begun businesses. However, young people in Malawi said parental sickness reduces capital availability. Borrowing money from parents during the 'window of opportunity' between school and marriage may prove impossible. Equally, sick parents can call on the income of businesspeople, as young Malawians revealed in the following discussion extract, immediate pressures compromising future possibilities:

Assistant: How does it affect the future of youths whose parents are sick?

Participant 1: Your future is doomed

...

Participant 2: If you were doing business, your capital is used up

Assistant: Why is it used up?

Participant 3: It is used up because you are at home and use the money in helping your parents

As a long-term livelihood trajectory, the efficacy of business is questionable. Most business ventures ultimately collapsed. However, failure need not imply livelihood vulnerability unless money has been borrowed: businesses generally generate short-term income and provide valuable experience and contacts, if not capital accumulation for further investment. Myriad causes precipitated failure: theft of money, tools or materials; lack of appropriate skills (including basic accounting); and 'eating the capital', prioritising current consumption over future benefits (Hajdu et al 2011). In many cases failure resulted from unpredictable circumstances, sometimes probably AIDS-related. Rex, for instance, successfully traded fish for several years. His business folded partly because he spent capital saved for the next fish purchase on a funeral for his one-year-old daughter. AIDS may challenge young people's capacity to invest for the future, encouraging them to prioritise present needs. However, assets accumulated through businesses can be liquidated during crises or provide short-term income-earning possibilities. In contrast to schooling or herding, business allows easy reprioritisation between current and future 
Ansell N, Hajdu F, van Blerk L, Robson E (in press, 2014) 'Reconceptualising temporality in young lives: exploring young people's current and future livelihoods in AIDS-affected southern Africa' Transactions of the Institute of British Geographers

needs. As Patric observed of the money he earned from dimba cultivation, 'You can keep it and use it for something, or when there is no soap you can take the money'.

The iteration between present and future in starting a business again differs from other pathways, illustrating the diverse temporalities of youth transitions. Far from a linear transition to working adulthood, businesses are often short term routes to other goals: another business or even a return to school. More than other pathways, business ventures reveal how outcomes often reflect unanticipated events as much as strategic intent. Transitions emerge incrementally, falteringly, influenced by experience, needs and expectations.

\section{Migrant work}

In both Malawi and Lesotho, livelihood trajectories often involve migration. Historically, livelihoods in rural Lesotho depended heavily on remittances from migrant mineworkers; most men spent some years mining. Between 1990 and 2006, however, the number of Basotho miners fell from 100,000 to 46,000 (Crush et al 2010). Meanwhile, East Asian firms established garment factories which now employ over 40,000 young, female 'internal migrants' on paltry wages (ibid). Additionally, many rural Basotho migrate for other work in Lesotho or sometimes South Africa, and most rural communities still rely on remittances (ibid).

Malawi, too, has a history of male labour migration to South Africa, which largely ended in 1987 following a dispute over HIV testing. Nonetheless, migration remains common: the 2004/5 Integrated Household Survey found $17.2 \%$ of household heads had lived elsewhere in the previous 5 years, including $4.3 \%$ in another country. Migration between rural areas was most common, and education, work and business the main reasons (Republic of Malawi 2005).

As our research was confined to village residents, we have no data from long-term or permanent migrants. However, seven of the 20 young people interviewed in Ha Rantelali and 10 of the 27 in Nihelo had previously migrated for work and recounted their experiences and rationales. Some had worked in multiple occupations, and among former domestic workers, most had changed employer at least once. In general the girls from Nihelo had migrated aged 13-15, although Emily was only 10 when she went 
Ansell N, Hajdu F, van Blerk L, Robson E (in press, 2014) 'Reconceptualising temporality in young lives: exploring young people's current and future livelihoods in AIDS-affected southern Africa' Transactions of the Institute of British Geographers

with her brother to make bricks. The girls in Lesotho were older at 16-18. The young men from Nihelo were generally around 18, although Mussa had worked as a watchman in Lilongwe and Zomba, gardenboy in Blantyre and on macadamia nut fields in Nasoniya by the age of 15 . Some Basotho boys had been found herding work at 8 or 9 . Employment was not necessarily easy to find. Some participants had sought work and failed, including four from Nihelo who had sought employment on the estates (one 18-year-old was told he was too young) and two young woman from Ha Rantelali who stayed with relatives in Maseru. Several Lesotho herdboys complained that caring for animals prevented them from seeking work and, as Mote remarked, 'Besides, it is not easy to get a job'.

Although some young people aspired to move permanently to pursue a more prosperous life, migrant work was often viewed as a short-term strategy within a larger plan; a way of saving money toward investing in further education or training. Paternal orphan, Manthlomeng (20) explained: 'In five years' time I will be working [in town] and in ten years I will be able to continue my studies'. Five months later she was working in town. Similarly, Masefali (14) planned to work in a garment factory to earn her school fees ultimately to become a doctor. Factory work was also valued for imparting sewing skills which were transferable to rural enterprise. Some made detailed plans, drawing heavily on social networks. Young people with urban relatives made speculative visits, hoping to find employment. Others seized opportunities as they arose, for instance when employers' representatives visited Nihelo recruiting unskilled labour.

Outcomes of migrant work were mixed. , Very few domestic workers saved enough to invest in their longer-term future and most left their employment upon marriage. Agricultural estate work was poorly paid (lower even than ganyu) and generally considered worthwhile only in the absence of any alternative support for immediate subsistence. Being physically gruelling, few stayed more than a few months. While girls in Ha Rantelali envisaged using factory work to save for further education, families of migrant daughters reported that low wages and high urban living costs left them unable to remit funds, even to support their own offspring. While envisaged as a future-oriented activity, even current needs were inadequately addressed. Moreover, sex work (reportedly practised by factory workers who lack regular contracts) and sexual abuse (reported by three former domestic workers) threaten longterm livelihoods by affecting health and social status. 
Ansell N, Hajdu F, van Blerk L, Robson E (in press, 2014) 'Reconceptualising temporality in young lives: exploring young people's current and future livelihoods in AIDS-affected southern Africa' Transactions of the Institute of British Geographers

Despite the importance of social networks, AIDS did not noticeably influence propensity to undertake labour migration. Equal numbers of affected and unaffected Ha Rantelali youth were working elsewhere, and roughly equal numbers had done so previously. The pattern was similar in Nihelo. Moreover, job types did not differ between those affected and unaffected. Two AIDS-affected young women in Ha Rantelali had stayed with relatives in Maseru and sought work unsuccessfully, but nothing indicated their failure related to their family situations: both had relatives to stay with, albeit not indefinitely. Some young people in Nihelo were apparently assisted by urban relatives to find work because they were orphans.

AIDS perhaps encouraged some young people to focus on the present rather than the future. Asked why she had gone to Blantyre to work, Milka, echoing other orphans, replied 'The problems were getting worse, soap, clothes'. For one participatory activity, young people created dramas exploring difficulties they faced. The young Malawian women portrayed a poor family where the father had died. The mother pointed to the daughters: 'you go and get married; you go and find work; you stay here and help me in the house'. Family crises of this nature incite strategic thinking that may be partly future-oriented. Relatives undoubtedly influence young people's actions, and impacts of AIDS shape incentives for familial investment in their futures (van Blerk and Ansell 2007).

While labour migration perhaps represents a more pivotal moment than some other livelihood pathways, its causes and effects stretch across this boundary demonstrating the interplay of present and future in constructing youth transitions. Like other pathways, it represents a response to immediate need and/or a stage in a long-term plan. While often temporary, it may enhance or deplete livelihood assets, with long-term consequences.

\section{Temporalities in the forging of livelihood trajectories}

Geographers need to be alert to how the future figures in various ways in young people's livelihood trajectories. Education is not the only livelihood activity pursued in relation to futurity: all the pathways discussed above may support accrual of livelihood assets in anticipation of future benefits. Southern African youth transitions do not entail a simple shift from future-oriented schooling to livelihoods 
Ansell N, Hajdu F, van Blerk L, Robson E (in press, 2014) 'Reconceptualising temporality in young lives: exploring young people's current and future livelihoods in AIDS-affected southern Africa' Transactions of the Institute of British Geographers

focused on immediate needs. However, while all livelihood activities influence the future, young people differ in their ability or inclination to focus on the future.

Some young people plan very strategically to secure future reward. Wilson, for instance, undertook building work to pay his school fees. While he saw money-earning potential in building, he told us 'it is not enough in my life'. Drawing on his education, he had applied for a temporary hospital job dispensing medication. He had detailed plans for a fish trading business with his brother, once he finally left school, but ultimately wanted to be a truck driver.

Strategic thinking was not confined to those whose present needs were secured, nor to older youth, as Emily's account made clear:

Emily: $\quad$ I saw that even if I continued school, there was no soap, no clothes, better just to leave it ... In terms of assistance, I saw that even if I continued [in school] it would have failed. Better if I worked to help myself.

Interviewer: Were thinking of this when you were a child aged nine?

Emily: I was thinking of that at the age of nine. I grew up in size and knowledge. You know, when you are in problems ...

By contrast, other young people admitted to thinking little about the future - particularly young married women in Malawi such as Irene, who felt relatively secure but lacked capital to invest. Some were sceptical about planning: Milka commented 'You can't talk about the future when you don't know where you're going'. Some were curious about the future and open to alterative outcomes. Rex remarked: 'If there was someone to pay the fees I could have continued and started Form 1 to see what could have come next'.

There is, however, no simple dichotomy between activities geared to the present or the future: for most participants, present and future were continuous and on-going. This on-goingness is apparent in Letsema's comment 'this is where I earn a living, so if I leave the animals I will not have something for survival' and Hlobola's declaration 'I can go to town to find work only if thieves come and take the very animals that I expect will give me life'. Some young people spoke not of a future substantially different 
Ansell N, Hajdu F, van Blerk L, Robson E (in press, 2014) 'Reconceptualising temporality in young lives: exploring young people's current and future livelihoods in AIDS-affected southern Africa' Transactions of the Institute of British Geographers

from the present, but of security and a permanent job. Moreover, securing the future can mean an urgent shift of focus in the present, as many herdboys suggested. Responding to the present and future does not involve simply balancing demands.

Lastly, livelihood activities are not undertaken only to secure current and future livelihoods, but also in relation lifestyles. Mamoletsane, commented 'a person has so many wishes and plans. I plan to have my own house and to live a nice and peaceful life'. Similarly, lifestyle priorities may intervene in the present, as Patric admitted in relation to education: 'When you prioritise playing, things don't go as well in the future'.

\section{Conclusions}

In this paper we have explored temporal aspects of young people's livelihoods. We conclude by summing up the paper's three main contributions: reworking the concepts of livelihood pathways and trajectories to enhance understanding of how individuals come to pursue particular livelihoods over time; questioning the impacts of AIDS on livelihoods; and furthering the conceptualisation of youth transitions.

In relation to livelihoods, we have reworked De Haan and Zoomers' (2005) concepts of livelihood pathways and trajectories, incorporating a temporal dimension. By focusing on ideas and aspirations as well as actions and looking both at how young people consider current needs and future aspirations in making decisions, and how their current activities affect future prospects, we have demonstrated that livelihoods are developed through iteration between present circumstances and future aspirations. Young people make plans, and invest time, money and effort in schooling, acquiring skills, placing themselves in a position to find jobs and starting businesses; moreover, the jobs they undertake and business ventures they launch are often part of a longer term strategy. Thus, livelihood actions are produced partly through deliberation on the future implications for themselves and their families (their parents, guardians, siblings, spouses, children), although these are not the only factors that play a role. Moreover, while some build assets they can employ later (financial, skills, social networks), an array of 
Ansell N, Hajdu F, van Blerk L, Robson E (in press, 2014) 'Reconceptualising temporality in young lives: exploring young people's current and future livelihoods in AIDS-affected southern Africa' Transactions of the Institute of British Geographers

factors intervene and the outcomes of young people's livelihood choices are not always as they would wish.

In relation to AIDS, some young people's livelihood decisions and activities are affected by the pandemic, but the study suggests impacts are less than anticipated by Loevinsohn and Gillespie (2003) and others. Table I strikingly illustrates that in these communities, (indirect) experience of AIDS has had no apparent generalised impact on the principal livelihood activities young people undertake. AIDSaffected young people proceeded further through school than their unaffected counterparts and among those having left full-time education there is little evidence for a systematically different experience of employment or business, although there are specific stories of AIDS' impacts. The reason behind the absence of a systematic pattern perhaps relates to the ambivalent effect of AIDS on the balancing of priorities between present and future. AIDS, like other crises, may cause young people to focus on their present livelihoods (and those of their parents, siblings and other kin) at the expense of the future; alternatively, it might force young people and their parents/relatives to examine closely their future prospects and make plans. Moreover, for many young people factors other than AIDS significantly shape their livelihoods.

Finally, the paper contributes to the theorisation of youth transitions, building on and extending the argument made by geographers that transitions should be understood as processes of 'becoming' (Langevang 2008, Worth 2009). While it is increasingly acknowledged that youth transitions are not distinct lifecourse phases amenable to examination in temporally bounded terms, the temporality of transitions has not been fully theorised. Even where scholars observe the complexity (and indeed 'nonlinearity') of transitions, they tend to work from the perspective of a linear notion of time (Worth 2009). Valentine's (2003) assertion that transitions are not one-way, for instance, is rooted in the observation that young people cross and recross the multiple and blurred boundaries between childhood and adulthood, yet views the boundary as something to be crossed, rather than a temporal form that is productive in itself.

Worth (2009) problematises static or linear perspectives on transitions and, drawing on Grosz (1999), advocates theorisation of transitions focused on the future rather than the past. This resonates with our findings that many young people are perpetually envisioning their futures, and constructing their 
Ansell N, Hajdu F, van Blerk L, Robson E (in press, 2014) 'Reconceptualising temporality in young lives: exploring young people's current and future livelihoods in AIDS-affected southern Africa' Transactions of the Institute of British Geographers

current lives in relation to expectations and aspirations. However, we would argue that futureorientation offers only a partial perspective, and itself relies on a linear and unidirectional view of time. Our research suggests it is more useful to see transitions as perpetually stretched across boundaries, spanning time, space and relationships, drawing constantly on pasts and futures in constituting the present. The livelihood pathways approach offers valuable insight, emphasising the non-deterministic ways in which individual trajectories are shaped by 'historical repertoires' (de Haan and Zoomers 2005). Livelihoods - and transitions - emerge incrementally and relationally, influenced by individual and collective experience, needs and expectations. Thus, viewing temporality as multi-directional, transitions are not simply about moving forward from today to tomorrow; rather they are constructed from the iteration of present and future. Young people, as 'being and becoming', forge livelihoods in the present, in relation to present and future, and with their actions always also carrying implications for their own futures and those of wider society. This is significant not only in relation to the lives of young people in southern Africa, but in societies worldwide, Western and non-Western.

\section{References}

Abebe T 2007 'Changing livelihoods, changing childhoods: patterns of children's work in rural southern Ethiopia' Children's Geographies 5(1-2) 7-93

Abebe T 2008 'Earning a living on the margins: begging, street work and the socio-spatial experiences of children in Addis Ababa' Geografiska Annaler 90(3) 271-284

Abebe T and Kjorholt AT 2009 'Social actors and victims of exploitation: working children in the cash economy of Ethiopia's South' Childhood 16(2) 175-194

Ainsworth M and Filmer D 2006 'Inequalities in children's schooling: AIDS, orphanhood, poverty, and gender'World Development 34(6) 1099-1128

Ansell N 2002 "Of course we must be equal, but ...': imagining gendered futures in two rural southern African secondary schools' Geoforum 33(2) 179-194 
Ansell N, Hajdu F, van Blerk L, Robson E (in press, 2014) 'Reconceptualising temporality in young lives: exploring young people's current and future livelihoods in AIDS-affected southern Africa' Transactions of the Institute of British Geographers

Ansell N, Hajdu F, van Blerk L, Robson E 2012 'Learning from young people about their lives: participatory methods and the production of empirically grounded accounts' Children's Geographies 10(2) 169-186

Bailey AJ 2009 ‘Population geography: lifecourse matters’ Progress in Human Geography 33, 407-418

Bissell S L, Kimane I and Mturi A J 2000 Rapidly assessing children at work in Lesotho: Volume 1, NUL in collaboration with UNICEF

BOS 2008 Integrated labour force survey 2008, Bureau of Statistics, Maseru

Bourdillon M (ed) 2000 Earning a life: working children in Zimbabwe Weaver Press, Harare

Boyden J and Ennew J (eds) 1997 Children in focus: a manual for participatory research with children Radda Barnen, Stockholm

Bryceson D 2006 'Ganyu labour, famine and HIV/AIDS in rural Malawi: causality and casualty' Journal of Modern African Studies 44(2) 173-202

Cass N and Walker G 2009 'Emotion and rationality: The characterisation and evaluation of opposition to renewable energy projects' Emotion, Space and Society 2(1) 62-69

Chambers R and Conway GR 1991 'Sustainable rural livelihoods: practical concepts for the 21st century', IDS Discussion Paper 296, Brighton

Chant S and Jones G 2005 'Youth, gender and livelihoods in West Africa: perspectives from Ghana and the Gambia' Children's Geographies 3(2) 185-199

Conticini A 2005 'Urban livelihoods from children's perspectives: protecting and promoting assets on the streets of Dhaka' Environment and Urbanization 17(2) 69-81

Crush J, Dodson B, Gay J, Green T and Leduka C 2010 Migration, remittances and 'development' in Lesotho Southern African Migration Programme/Idasa, Cape Town

Dahlblom K, Herrara AR, Pena R and Dahlgren L 2009 'Home alone: children as caretakers in Leon, Nicaragua' Children and Society 21(1) 43-56 
Ansell N, Hajdu F, van Blerk L, Robson E (in press, 2014) 'Reconceptualising temporality in young lives: exploring young people's current and future livelihoods in AIDS-affected southern Africa' Transactions of the Institute of British Geographers

de Haan L and Zoomers A 2005 'Exploring the frontier of livelihoods research' Development and Change 36(1) $27-47$

Dorward AR, Mwale I and Tuseo R 2006 'Labor market and wage impacts of HIV/AIDS in rural Malawi' Review of Agricultural Economics 28(3) 429-439

Evans R 2006 'Negotiating social identities: the influence of gender, age and ethnicity on young people's 'street careers' in Tanzania' Children's Geographies 4(1) 109-128

Grieco M, Apt NA and Turner J (eds) 1996 At Christmas and on rainy days: transport, travel and the female traders of Accra Avebury

Grosz E 1999 Becomings: explorations in time, memory and futures Cornell University Press, Ithaca Hajdu F, Ansell N, Robson E, van Blerk and Chipeta L (in press 2011) 'Income generating activities for young people in Southern Africa: exploring AIDS and other constraints' Geographical Journal

Hampshire K, Porter G, Kilpatrick K, Kyei P, Adjaloo M and Oppong G 2008 'Liminal spaces: changing inter-generational relations among long-term Liberian refugees in Ghana' Human Organization 67(1) 2536

Harker C 2005 ‘Playing and affective time-spaces’ Children's Geographies 3(1) 47-62

Heady C 2000 What is the effect of child labour on learning achievement? Evidence from Ghana, UNICEF Innocenti Research Centre, Florence

Hopkins P and Pain R 2007 'Geographies of age: thinking critically' Area 39(3) 287-294

Horton J and Kraftl P 2006 'Not just growing up, but going on: materials, spacings, bodies, situations' Children's Geographies 4(3) 259-276

Horton J, Kraftl P and Tucker F 2008 'The challenges of 'Children's Geographies' a reaffirmation' Children's Geographies 6(4) 335-348

Jaiyebo 02003 'Women and household sustenance: changing livelihoods and survival strategies in the peri-urban areas of Ibadan' Environment and Urbanization 15(1) 111-120 
Ansell N, Hajdu F, van Blerk L, Robson E (in press, 2014) 'Reconceptualising temporality in young lives: exploring young people's current and future livelihoods in AIDS-affected southern Africa' Transactions of the Institute of British Geographers

James A, Jenks C and Prout A 1998 Theorising childhood Teachers College Press, New York

Jeffrey C 2010 'Geographies of children and youth I: eroding maps of life' Progress in Human Geography 34(4) 496-505

Johnson-Hanks J 2002 'On the limits of the life cycle in ethnography: toward a theory of vital conjunctures' American Anthropologist 104(3) 865-880

Katz C 2004 Growing up global: economic restructuring and children's everyday lives University of Minnesota Press, Minneapolis

Kesby M 2000 'Participatory diagramming: deploying qualitative methods through an action research epistemology' Area 32(4), 423-435

Langevang T 2008 'We are managing!' Uncertain paths to respectable adulthoods in Accra, Ghana' Geoforum 39, 2039-2047

Langevang T and Gough K 2009 'Surviving through movement: the mobility of urban youth in Ghana' Social and Cultural Geography 10, 741-756

Lefoka P J 2006 'Out of school missing boys: a study from Lesotho' in Commonwealth Secretariat (ed) Commonwealth Education Partnerships 2007 Commonwealth Secretariat, London

Loevinsohn M and Gillespie S 2003 HIV/AIDS, food security and rural livelihoods: understanding and responding, RENEWAL Working Paper No. 2, IFPRI, Washington DC

Mabala R 2011 'Youth and "the hood" - livelihoods and neighbourhoods' Environment and Urbanization 23(1) 157-181

MacDonald R, Mason P, Shildrick T, Webster C, Johnston L and Ridley I 2001 'Snakes and ladders: in defence of studies of transition' Sociological Research Online 5(4)

http://www.socresonline.org.uk/5/4/macdonald.html

Murray C 2002 'Livelihoods research: transcending boundaries of time and space' Journal of Southern African Studies 28(3) 489-509 
Ansell N, Hajdu F, van Blerk L, Robson E (in press, 2014) 'Reconceptualising temporality in young lives: exploring young people's current and future livelihoods in AIDS-affected southern Africa' Transactions of the Institute of British Geographers

Pain R 2004 'Social geography: participatory research' Progress in Human Geography 28(5), 652663Punch 2002 'Youth transitions and interdependent adult-child relations in rural Bolivia' Journal of Rural Studies 18(2) 123-133

Republic of Malawi 2005 Integrated Household Survey 2004-2005, National Statistical Office, Zomba Robson E 2004 'Children at work in rural Northern Nigeria: Patterns of age, space and gender' Journal of Rural Studies 20,193-210.

Robson E, Ansell N, Huber US, Gould WTS and van Blerk L 2006 'Young caregivers in the context of the HIV/AIDS pandemic in Sub-Saharan Africa' Population, Space and Place 12(2) 93-111

Teather E (ed) 1999 Embodied geographies: spaces, bodies and rites of passage Routledge, London UNAIDS 2010 Global report: UNAIDS report on the global AIDS epidemic UNAIDS, Geneva

UNICEF 2011 'Information by country and programme' http://www.unicef.org/infobycountry/index.html accessed 06/09/11

Uprichard E 2008 'Children as 'being and becomings': children, childhood and temporality' Children and Society 22 303-313

Valentine G 2003 'Boundary crossings: transitions from childhood to adulthood' Children's Geographies, 1(1) $37-52$

van Blerk L 2008 'Poverty, migration and sex work: youth transitions in Ethiopia' Area 40, 245-253

van Blerk L and Ansell N 2007 'Alternative caregiving in the context of HIV/AIDS in southern Africa: complex strategies for care' Journal of International Development 19(7) 865-884

Worth N 2009 'Understanding youth transition as 'Becoming': Identity, time and futurity' Geoforum 40, $1050-1060$

Yin R K 1994 Case study research Sage, Thousand Oaks 